\title{
Article
}

\section{Social Media Activities and Its Influence on Customer-Brand Relationship: An Empirical Study of Apparel Retailers' Activity in India}

\author{
Sukanya Sharma $^{1}$, Saumya Singh ${ }^{1, *}$, Fedric Kujur $^{1}$ and Gairik Das ${ }^{2}$ \\ 1 Department of Management Studies, Indian Institute of Technology (Indian School of Mines), Jharkhand, \\ Dhanbad 826004, India; sukanya.2014dr1012@ms.iitism.ac.in (S.S.); fedrickujur@ms.ism.ac.in (F.K.) \\ 2 Department of Retail Management, Calcutta University, \\ Indian Institute of Social Welfare and Business Management, Kolkata 700073, India; gairikd@yahoo.com \\ * Correspondence: saumya@iitism.ac.in; Tel.: +91-0326-2235497; Fax: +91-0326-2296631
}

Citation: Sharma, S.; Singh, S.; Kujur, F.; Das, G. Social Media Activities and Its Influence on Customer-Brand Relationship: An Empirical Study of Apparel Retailers' Activity in India. J. Theor. Appl. Electron. Commer. Res. 2021, 16, 602-617. https://doi. org/10.3390/jtaer16040036

Received: 15 September 2020 Accepted: 16 December 2020 Published: 31 December 2020

Publisher's Note: MDPI stays neutral with regard to jurisdictional clai$\mathrm{ms}$ in published maps and institutional affiliations.

Copyright: (C) 2020 by the authors. Licensee MDPI, Basel, Switzerland. This article is an open access article distributed under the terms and conditions of the Creative Commons Attribution (CC BY) license (https:// creativecommons.org/licenses/by/ $4.0 /)$.

\begin{abstract}
In this digital era, the internet, and Social Media (SM) has had a radical impact on the shopping behavior of "costumers" The SM provides a platform where "costumers" are exposed to the best product with the best price along with reviews and opinions about the merchandise. So, we can turn our heads and look at a brand in a way as if the brand is speaking to us. This study was an attempt to explore the Social Media Marketing Activities (SMMA) that are being used for the marketing of fashionable products like apparel and to what level the SMMA activities of brands truly strengthen the relationship with customers and motivate purchase intention. Moreover, SMMA has a robust application in developing a marketing strategy for business. It has become a significant tool that collaborates with businesses and people. It is concluded that the "costumer"brand relationship does have a positive and statistically significant impact on consumers' purchase intention through SM.
\end{abstract}

Keywords: social media; social media marketing; apparel industry; purchase intention; brand relationship

\section{Introduction}

To date, millions of people are using social media (SM) across the globe through website-based network applications that help to share knowledge, information, and easy connections with each other [1-7]. People are using SM to fulfill a variety of needs especially looking for digital content and products [7-9]. It makes people feel good, gives a positive self-outlook, especially with the young age groups, who get a boost in their self-esteem [10].

$\mathrm{SM}$ has provided a new horizon in the field of marketing as e-commerce, thereby giving prospects to the marketers for generating consciousness of products amongst customers $[1,11]$. It is well-established tool that increases public relations through the collaborating method. It is a collection of communication through networks in which individuals disseminate information, expectations, comments, explanations, and predictions [12]. It has brought people around the world into a common interactive platform where opinion, reviews, and information are shared [13,14].

Moreover, SM has largely expanded the apparel business in India [15], which is the major contributor in the marketing arena and holds the second position after food and groceries [16]. SM is influencing the apparel sector, which helps to grasp the massive viewers in systematic manner. Interestingly, SM plays a vital role in consumer communication, which in turn creates cognizance, engrossment, and engagement for various brands and obtained visibility in augmented purchase behavior [6,11,16-18]. The "Word of Mouth" (WOM), a marketing tool that driving the apparel industry, which is also spreading rapidly through SM platforms, which has a gradual increase user base [11,13,14,16,19]. SM has 
become an information funnel which millions of eyes pass through every minute, thereby $\mathrm{SM}$ can be an effective tool for apparel retailers [15].

The twenty-first century has witnessed fashion and apparel designers using social networking sites (SNS), which have become prioritized [15]. "Costumers" view the products as if they are talking to them, and the reviewing of brands make a lot of fans. The fashion designers and their different brandings can only comprehend the factual value of $\mathrm{SM}$, which is having enormous supporters or fans [15].

Digital or SM lays an imprint on the behavior of people. Interestingly, various information and social elements received through SM in the form of reviews or comments work magic in the mind of consumers. Lamberton et al. [20] and Norton et al. [21] mentioned the importance of information derived from others in digital atmospheres. They found that in SM, there is an interpersonal exchange of opinions from various "costumers". A lot of dissimilarity arises, and consequently, instead of enhancing confidence level, it reduces the same if the opinion of others is not similar and while they have made the same choice. Adopting a different perspective, Wilcox and Stephen [22] opined that when people use Facebook and the suggestion is from a very close friend circle, it lowers self-control in choosing a product with lesser benefits.

As stated by Pham and Gammoh [23], currently the most extensively accepted SM platforms are "Facebook", "Twitter", and "YouTube" for sharing fashion contents. Owners of many luxury brands have made personal Twitter accounts, or they uploaded on Facebook [24]. Communication in the modern day is not one way, rather "costumers" and brands are interacting with one another irrespective of time, place, or any other medium. This helps to strengthen relations with clientele. It is an established approach for collaborating between brands and customers, ultimately producing novel products, services, innovative business model, and standards [25].

The brands of apparel products are reinforcing association with "costumers", and since the major portion of SM users are youngsters, social media marketing activity (SMMA) is instigating the accustomed emotions linked with current luxury brands to those who belong to a younger age group. Besides, the various happenings of SM of brands offer a chance to diminish misinterpretation and preconception toward brands, and to raise brand worth based on the interchange of information and ideas amongst the online publics $[6,15,17,26-28]$.

SM is spreading its' petals in the business domain and has become an effective tool for marketing activities. It also encompasses customer relations and gives a boost for purchasing. The social network platform gives a value-added track to the possible customers and targeted merchandise. The SM makes a connecting link between the brand and probable customers $[15,26]$. Hence, the present stud attempted to measure how the SMMA and brands relationship with customers that motivate the purchase intention of the apparel as per retailers' activity in the context of the eastern India.

\section{Literature Review}

Relevant literature related to marketing activities through SM including SMMA and customer-brand relationships related to purchasing intentions in the case of apparel products are compiled and presented as follows:

\subsection{Social Media Marketing Activities}

The functioning of SMMA is based on marketing activities within SM platform. As pointed by Pham and Gammoh [23], currently the most extensively accepted SM platforms are mainly "Facebook", "Twitter", and "YouTube", websites designed to share different content. As opined by Stephenson [24], Twitter is the human accent for publicity, and fashion designers use Twitter and blogs (SM platforms) to shape their brand personality, and use them as sources of advertising. Olivier [29] mentioned that SM has contributed to innovative elements into online shopping and acts as a vehicle for extra profit, thereby giving retailers a chance to display their products to thousands of probable customers. Moreover, SM is an online application which enables communications, collaborations, and 
the distribution of content [30]. As mentioned by Kim and Ko [25], the impact of SM on a specific brand is marvelous and imprints a vivid picture in the mind of customers. The relationship between the firm, brand, and social media is interdependent, interwoven, and interlinked.

The mechanism of SM has been previously discussed by various authors in different contexts and environments. A study by Kim and Ko [27] carried out research to determine enhanced customer equity through SMMA in the context of premium brands. They classified SMMA into five categories, namely "entertainment", "interaction", "trendiness", "customization", and "word-of-mouth (WOM)" to explore their impact on customer equity in Facebook brand pages. Later, Yadav and Rahman [28] developed scales for SMMA and validated them based on consumer perceptions in the context of the e-commerce industry, and also checked the influence of SMMA within the e-commerce activities concerning "brand equity" and "purchase intention". The SMMA considered followed the abovementioned categories. Further, Bilgin [26] conducted a study on SMMA by considering five components to explore their impact on brand awareness, brand image, and brand loyalty in the SM environment. Yadav and Rahman [28] studied the apparel retailer's activities in relation to SMMA components as interactivity, informativeness, personalization, trendiness, and WOM communication, and they mentioned these components are the best fit for the e-commerce brands of the apparel industry. According to Kamboj et al. [31], the definition of life is changing due to the contribution of digital technologies. The application of artificial intelligence has gained momentum in the retail arena currently.

\subsection{Social Media Marketing Activities in the Apparel Retailers}

The advent of SM has brought about serious changes in the apparel sector, which has revolutionized communication and information sharing. As mentioned by Smith et al. [32], usage of SM, especially for marketing, advertising, generation of an innovative idea, etc. by companies is increasing, and from 2008 to 2012, it has grown from $42 \%$ to $88 \%$. In this volatile business environment, interacting and engaging with customers is especially important, and SM helps to create brand loyalty.

Burmann [33] and Rialti et al. [34] explained that in the era of SM, loyal consumers become the brand ambassador for others who are influenced by the reviews. Reviews and information act as a recommendation, which consequently enhances purchase intentions and persuades them to buy. In an earlier study, Ahmad et al. [13] reported that SM is a suitable and cheap communication platform in which the sustainability of the fashion industry is observed. Sarkar et al. [15] established that marketing of apparel products through SM achieved consumer preferences.

\subsection{Customer-Brand Relationship}

As an established fact, customer is the king, and the origin of the sustainability of any business is the customer. Ujur and Singh [17] mentioned for the past few decades, customer relationship management has gained momentum, which is evident from many theories designed to build customer relationships.

Interpersonal relationship theories were being used by Hon and Grunig [35], and they thereby recognized six relationship parameters, which are extensively accepted. These are known as "trust", "satisfaction", "commitment", "control mutuality", "exchange relationship", and "communal relationship" [36,37]. It has been established that the former three parameters have already been well-thought-out as a degree of a suitable relationship. Therefore, in this context, these three above-mentioned parameters have been selected to determine the quality of the relationship between customers and brands.

Trust discusses both parties' desire and confidence in a relationship that opens to one another [17]. From a past study, Hon and Grunig [35] reported that trust contains three distinct attributes viz. "integrity", "dependability", and "competence". If the one candidate shows dependability and competence, then it specifies that the candidate is "willing and able to do what it says it will" [38]. Hung [39] stated that satisfaction can be 
an optimistic emotion regarding the other candidate, which they may cherish from positive anticipation of associations.

The commitment refers to the craving of both candidates to fortify an association [40]. Previous research has recognized two types of commitment viz. "continuance commitment" and "affective commitment". The former is defined as commitment proceeding to a specific line of activity on affective commitment, and the second one is referred as the emotional relationship to an organization [40].

On the other hand, Kujur and Singh [41] reported that YouTube is the most innovative SNS, where consumers are allowed to post, view, comment, and link to videos on the site regarding brand activities. They investigated that emotional appeals are being used in SNS like YouTube advertisements for promotion of their products through big brands of different sectors in an emerging market like India. Further, Kujur and Singh [17] proposed a theoretical model based on the consumer-brand relationship through visual communications of consumers on corporate Social Networking Sites. According to them, SEM validated the effect of visuals with the content of information, entertainment, and remuneration for consumer engagement to determine the consumer-brand relationship.

\section{Conceptual Framework and Hypotheses Testing}

\subsection{SMMA and Customer-Brand Relationship}

To create a "consumer-brand relationship", the "social exchange theory" acts an important role, which comprises two-way communications. Bortree [42] explained that a higher degree of interactivities or relationships with an institution may be strongly related to the clienteles. SMM activities (SMMA) with a brand on its pages of SNS attract the recognition of users of SM and initiates a recurrent and healthy exchange with their content, which provides a long-lasting affiliation to that nurture customers. Whereas Nammir et al. [43] explained that SMMA meaningfully bestows a productive association. Moreover, SM is considered as a wider basement for the suitable system of development of the relationship, and rare studies have found the impact of SMMA on developing customerbrand attachment. Hence, the present work was engrossed to know the degree of SMMA impacts on the customer-brand relationship followed by purchase intention. The customerbrand relationship is a mediating variable between SMMA and purchase intention.

\subsection{Purchase Intention}

The intention to buy is a mixture of the interests of customers and the opportunity to buy a product. Intention to buy is generally connected to "costumer" behavior, perceptions, and attitudes which help in accessing and evaluating the products $[18,44]$. As a consequence of many reports, the attitudes and preferences for a brand or product are closely linked so that measurement of purchase intention takes the future conduct of customers into account based on their attitudes $[28,45]$. The intention to purchase is a behavioral variable to assess prospective buyers who can contribute to a brand, while the behavioral variable accounting for real buying records is customer equity. Since forecasting the future conduct of customers becomes an imperative problem for an organization, future conduct should be more reliably evaluated [27].

As coined by Diallo [46], the consumer purchase intention for a product or service identifies the purchase effort. An optimistic and good feeling attitude for a product or service stimulates one's purchase intention [47]. According to Das [47], several aspects contribute to the purchase intention from an apparel retail store like the site of the store, variety or brands sold, and also fulfilling some basic needs as per the demand of customers in an improved way [48]. Therefore, the proposed hypothesis is developed as follows:

Hypothesis 1: Perceived SMMA has a positive impact on the "costumer"-brand relationship followed by purchase intention. 


\subsection{Perceived SMMA and Purchase Intention}

Brands' SMMA provides an avenue to lower misunderstandings and biases towards brands and an increasing value-added brand by establishing a principle for online users to interact with their opinions and information [27]. Companies embrace SM for multiple operations such as brand development, research in marketing, relationship management on the customer, provision for service, and promotion for sales in markets in conjunction with numerous studies showing the beneficial impact of SM deployment on marketing strategies [49].

With the help of SM channels, business organizations are communicating with new and existing consumers by conveying brand-related information at low cost and less work than before by using various types of SM platforms like social blogs, weblogs, images, ratings, Wikis, and podcasts. SM messages lead to higher brand attitudes, enhanced word of mouth, and brand equity [50,51]. Social networks and blogs such as "Twitter" and "Facebook" are the best ways for businesses to enhance their attitude towards the brand [52]. Besides, SM could be used to produce enhanced revenues, "Return on Investment (ROI)", "Word-of-Mouth (WOM)" and communication related to the brand [53]. As customers receive data and communicate on SM with the brand, they create a connection with the brand that would contribute to brand loyalty and impact their buying intentions with a powerful positive attitude towards advertising and promotions. Therefore, the proposed hypothesis is developed as follows:

Hypothesis 2: Perceived SMMA has a positive effect on purchase intention.

\subsection{Customer-Brand Relationship and Purchase Intention}

Relationship quality plays a significant part in the study of customer-brand relations. For instance, trust, satisfaction, and commitment all have a significant impact on consumer buying behavior. The impact of satisfaction on readiness to pay was investigated by Homburg et al. [54], and also in a previous study by Verhoef et al. [55], where it was found that the relational dimensions like loyalty, satisfaction, and trust were associated with customer references and the number of services purchased. The study of Verhoef et al. [55] resulted to have significant influence on all three elements of the relationship on customer referrals and the only commitment dimension that was found to have a considerable impact on the number of services purchased. Cronin and Taylor [56] established that consumer buying behavior is highly influenced by customer satisfaction. Bloemer et al. [57] found that in different sectors, different elements of relationship quality were essential. Generally, the common belief is that the high quality of the relationship (or its elements) results in a correspondingly high level of intention to buy $[17,38,58]$. The conception is at par concerning the "general models of consumer behavior" resembling "Theory of Reasoned Action" as well as the "Theory of Planned Behavior" [59]. As per the above-mentioned models, the viewpoints can be assumed to know the behavioral intentions, which further leads to an exact behavioral response. From the metanalysis, Armitage and Connor [60] have concluded that this method is valid and suitable through a wider range of situations. Furthermore, the application of these models is restricted to a recently presented behavior, but their application is also fruitful in related customer-firm research [61]. In this context, the hypothesis is as follows:

Hypothesis 3: A perceived "costumer"—brand relationship has a positive impact on purchase intention.

Everchanging lifestyles, the rising economic situation, and the availability of various multi-branded apparel have necessitated that retailers know the factors that influence the purchase intention of branded garments. Purchase intention portrays the imprint of a loyal purchaser. Brands have got various facets that impact the purchase behavior of consumers. As highlighted by Motameni and Shahrokhi [62], the branding of apparel is a way to communicate with buyers. Kotler et al. [63] studied that brands regulate the buying patterns of goods. Branding facilitates competitive gain. Narang [64] and 
Kamalaveni et al. [65] stated that purchasing of branded clothes as well as garments is not impulsive. Consumer sensitivity regarding the value of a product is based on three factors, quality, cost, and the degree of risk associated with it, which immediately impact willingness to buy [66]. In research carried out by Granot et al. [67], three concepts were identified that stimulate purchase decisions for (especially female) customers, which are "brand, service and experimental shopping". Out of these, the image on the brand has been appraised as a precursor of buying purpose for customers [68,69]. The image on the brand carries info regarding the superiority of products and their service quality. According to Erdil and Uzun [69], customer insight and marketing policies together make the brand image and gives sentinel satisfaction [70]. The image of any brand divulges worth and uniqueness shaped for buyers [71]. The conceptual model of the hypothesis testing is exhibited in Figure 1.

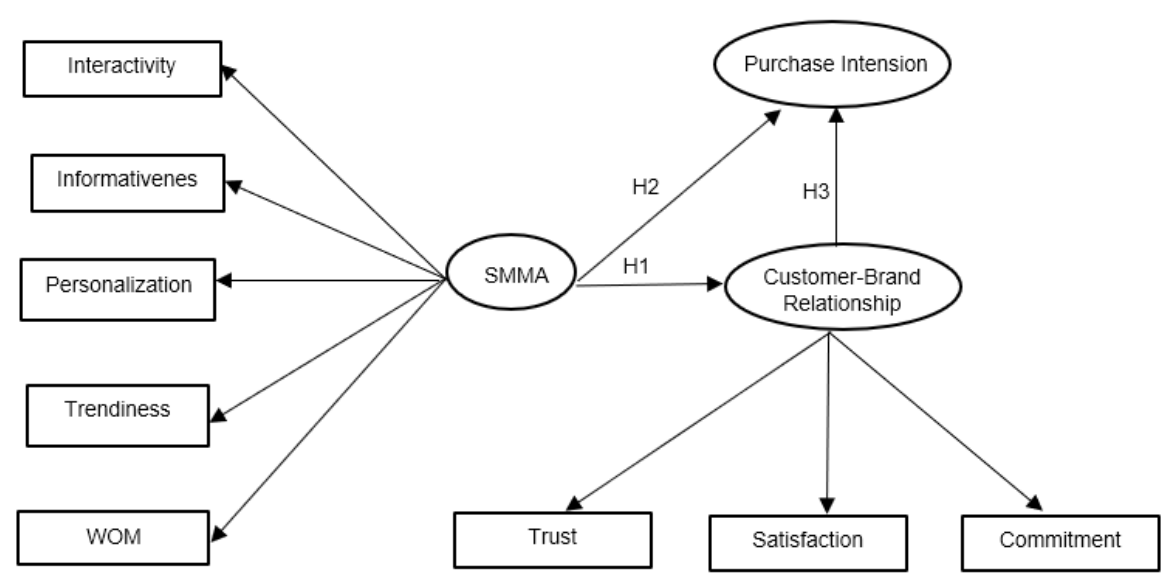

Figure 1. Conceptual model of the hypotheses testing.

\section{Material and Methods}

\subsection{Sampling Methods}

For the selection of the target sample, the residents of capital cities and metro city of eastern India were considered. Appropriate samples were collected from the three different cities located in the eastern part of India via the mall intercept method, since customers living there will in general be increasingly aware of buying fashion brands (Apparel brands) and equivalently high buying power for design brands. The respondents " $\geq 18$ years of age as minimum age limit were selected for the study. For the survey, respondents were firstly interrogated about the exposure of the fashion industry over SM platforms, mainly "Facebook", "Twitter", "YouTube", and "Instagram". Secondly, they were evaluated regarding their interest or preference for fashion brands, especially apparel brands in the present case. The participants who answered 'yes' were further considered for the full structured questionnaire-based survey. The present survey was conducted using offline mode, and the incentive was not issued to the participants due to the academic research. The questionnaire for this research has been drawn from prior literature and has been moderately altered to suit the objective of this research. The categorized questionnaire items are on a five-point Likert scale, varying from "strong disagreement" to "strong agreement" used in the present study.

\subsection{Data Collection Methods}

In this study, the samples were selected for about 305 participants. The data indicated that $38.2 \%$ of participants were males and $61.8 \%$ were females. About $56.1 \%$ of the participants ranged between the age group 18-25 years, 34.4\% belonged to $26-35$ years, $8.3 \%$ belonged to $36-45$ years, and $1.2 \%$ belonged to the age group above 45 years. Most of the participants, i.e., $61.3 \%$, were found to be unmarried, whereas $37.9 \%$ were married, and the rest were either separated or divorced. Many of the respondents had a graduation degree, 
i.e., $40.4 \%$, followed by post-graduation $22.0 \%$, higher secondary $20.5 \%$, and the rest were either below 10th pass or professionals. $31.7 \%$ of respondents said they visit malls once in a month for shopping, followed by $23.9 \%$ once in a week, $19.7 \%$ only on occasions, and $15.0 \%$ more than once in a week. About $74.6 \%$ of respondents agreed to visiting malls during offers and happy hour sales.

\subsection{Measures}

For measuring SMMA, a total of 15 items were taken from earlier reports with some modification [26-28,72,73]. The scales of SMMA have already been validated in the previous studies, which represented " 5 -dimensions of perceived SMMA" of fashion brands ("Interactivity", "Informativeness", "Word-of-Mouth (WOM)", "Personalization", and "Trendiness", with 3-types in individual aspect). Similarly, 10 items for measuring consumer-brand relationships were taken from this study, as per Grunig and Huang [40], which represented three relationship dimensions, namely trust, satisfaction, and commitment. Lastly, four items were for measuring purchase intention, as per Hung et al. [74] and Park et al. [75]. In the present investigation, all the studied items were adopted from the above-mentioned published articles. "Exploratory Factor Analysis (EFA)" was performed to find representative factors. Table 1 shows the selected item summary of EFA, which were analyzed with 29 variables by dividing nine latent variables or factors.

Table 1. Definitions of items summary.

\begin{tabular}{|c|c|c|c|}
\hline $\begin{array}{l}\text { Second-Order } \\
\text { Construct }\end{array}$ & $\begin{array}{l}\text { First Order } \\
\text { Construct }\end{array}$ & $\begin{array}{l}\text { Indicator } \\
\text { Code }\end{array}$ & Definition of Items Summary \\
\hline \multirow{15}{*}{$\begin{array}{c}\text { Social Media } \\
\text { Marketing Activities } \\
\text { (SMMA) }\end{array}$} & \multirow{3}{*}{ Interactivity } & Inter1 & Facebook fashion brand pages enable me to share information with others \\
\hline & & Inter2 & $\begin{array}{c}\text { Discussion or exchange of opinion with others is possible through Facebook fashion } \\
\text { brand pages }\end{array}$ \\
\hline & & Inter3 & Easy delivery of my opinion through Facebook fashion brand pages \\
\hline & \multirow{3}{*}{ Informativeness } & Info1 & Facebook fashion brand pages offer accurate information on products \\
\hline & & Info2 & Facebook fashion brand pages offer useful information \\
\hline & & Info3 & The information provided by Facebook fashion brand pages are comprehensive \\
\hline & \multirow{3}{*}{ Personalization } & Pers1 & Facebook fashion brand pages offer customized information search \\
\hline & & Pers2 & Facebook fashion brand pages provide customized service \\
\hline & & Pers3 & Facebook fashion brand pages give me recommendations as per my requirements \\
\hline & \multirow{3}{*}{ Trendiness } & Trend1 & Contents shown in Facebook fashion brand pages is the newest information \\
\hline & & Trend2 & Using Facebook fashion brand pages is very trendy \\
\hline & & Trend3 & Anything trendy is available on Facebook fashion brand pages \\
\hline & \multirow{3}{*}{ Word-of-Mouth } & WOM1 & $\begin{array}{c}\text { Sharing by me for information on the brand, product, or services from Facebook } \\
\text { fashion brand pages to my friends }\end{array}$ \\
\hline & & WOM2 & Recommendations by me to my friends to visit Facebook fashion brand pages \\
\hline & & WOM3 & Encouragment by me to my friends and aware to use Facebook fashion brand pages \\
\hline \multirow{10}{*}{$\begin{array}{l}\text { Costumer-Brand } \\
\text { Relationship (CBR) }\end{array}$} & \multirow{3}{*}{ Trust } & TR1 & A particular brand treats me fairly and justly \\
\hline & & TR2 & A particular brand can be relied up to keep its promises \\
\hline & & TR3 & It is my belief that this brand takes opinions into account to make decisions \\
\hline & \multirow{3}{*}{ Satisfaction } & Sat1 & A brand and I benefitted from the relationship \\
\hline & & Sat2 & Most people like me are happy in their interactions with this brand \\
\hline & & Sat3 & $\begin{array}{l}\text { Through speaking, I am pleased with the relationship this brand has established } \\
\text { with me }\end{array}$ \\
\hline & \multirow{4}{*}{ Commitment } & Com1 & I feel that this brand is trying to support a long-term commitment for me \\
\hline & & Com2 & I can see that this brand wants to keep a relationship with me \\
\hline & & Com3 & There is a permanent bond between this brand and me \\
\hline & & Com4 & I would rather work together with this brand than not \\
\hline
\end{tabular}


Table 1. Cont.

\begin{tabular}{lccc}
\hline $\begin{array}{c}\text { Second-Order } \\
\text { Construct }\end{array}$ & $\begin{array}{c}\text { First Order } \\
\text { Construct }\end{array}$ & $\begin{array}{c}\text { Indicator } \\
\text { Code }\end{array}$ & Definition of Items Summary \\
\hline & & PI1 & I will purchase the brands recommended by my friends on social media (SM) sites. \\
\cline { 3 - 4 } $\begin{array}{c}\text { Purchase } \\
\text { Intention }\end{array}$ & PI2 & I will purchase the brands as marketed on social media sites the next time I need \\
\cline { 3 - 4 } & & PI3 product \\
\cline { 2 - 4 } & & PI4 & I will try the brand as marketing on social media sites \\
\hline
\end{tabular}

\section{Results}

\subsection{Confirmatory Factor Analysis}

Confirmatory factor analysis (CFA) was done for testing the stability of construct measurement as per the researcher's understanding to know the nature of that constructs or factors.

CFA First Order analysis was evaluated to confirming each indicator variable, as per the theory from earlier findings or related to the present study. The combination was done for all variables like exogenous and endogenous in the CFA analysis as "pooled CFA". As per Chong et al. [76], the results of "pooled CFA" are easily known compared to the "individual CFA", which is based on a shorter duration "measurement model". Table 1 tabulates on 29 anlayzed "observed variables", which further divided into 9 "latent variables". The "observed variables" are also termed as the "variables of the indicator". Out of 9 factors, 5 factors are related to SMMA, and 3 factors are related to the consumerbrand relationship, and one factor is about purchase intention. The present study has applied the "measurement model" to use First Order Confirmatory Factor Analysis (CFA) and to determine the validity and reliability of the construct, and all item indicators were developed. The latent variables were also analyzed in a "pooled CFA First Order Analysis".

The "second-order CFA" is another statistical method to establish the "theorized construct loads" followed by a study with a definite quantity of "underlying sub-constructs". The present study indicates SMMA and "Consumer-Brand Relationship" are the main constructs. The sub-constructs of SMMA are "Interactivity", "Informativeness", "Personalization", "Trendiness", and "Word-of-Mouth", and the sub-constructs of "Consumer-Brand Relationship" are "Trust", "Satisfaction", and "Commitment". Thus, the section CFA has been divided into two sub-sections, which are "CFA First Order" and "CFA Second Order".

In the present study, there were 29 "observed variables" as designated the "latent variables" as per specific categories found as per established theories, models, and earlier studies. All the "observed variables" were estimated for the factor structures. The association between the "latent variables" and the "indicator variables" were estimated by the factor loadings. Several researchers explained that the factor loading value should be $\geq 0.70$ [77-80]. However, as per earlier findings, $\geq 0.50$ can still be accepted when other assumptions in the model fitness such as "root mean square error of approximation (RMSEA)", "comparative fit index (CFI)", "goodness of fit index (GFI)", and "Tucker-Lewis index (TLI)" were achieved [78,81,82].

\subsubsection{CFA First Order}

The results of the CFA First Order indicate a good measurement model fit of the proposed factor structure $(\mathrm{CMIN} / \mathrm{DF}=1.476, \mathrm{GFI}=0.905, \mathrm{NFI}=0.884, \mathrm{IFI}=0.959, \mathrm{TLI}=0.951$, $\mathrm{CFI}=0.959, \mathrm{PCFI}=0.805, \mathrm{RMSEA}=0.039, \mathrm{RMR}=0.038)$. Thus, the measurement model fitness was achieved in the pooled CFA First Order. To check multicollinearity data (high correlation), the convergent and discriminant analysis was conducted using stat tools package software. For measuring convergent validity, AVE value as $\geq 0.50$ was considered whereas, for discriminant validity, AVE $\geq$ MSV was considered. From Tables 2 and 3, the result finds no serious issues in the validity and reliability of each data. All findings concerning the "factor loadings", "construct validity", "reliability", and "model fit indices" 
represented that the data fulfilled all the prerequisites for the "CFA First Order" tests. The model measurement could have proceeded to the next level of test viz. the "CFA Second Order" as required in this study.

Table 2. Loadings of Confirmatory factor analysis (CFA) First Order.

\begin{tabular}{|c|c|c|c|c|c|}
\hline First Order Constructs & Code & CFA Loadings & C.R. & AVE & MSV \\
\hline \multirow{3}{*}{ Interactivity } & Inter1 & 0.774 & \multirow{3}{*}{0.796} & \multirow{3}{*}{0.567} & \multirow{3}{*}{0.123} \\
\hline & Inter2 & 0.806 & & & \\
\hline & Inter3 & 0.673 & & & \\
\hline \multirow{3}{*}{ Informativeness } & Info1 & 0.866 & \multirow{3}{*}{0.862} & \multirow{3}{*}{0.676} & \multirow{3}{*}{0.094} \\
\hline & Info2 & 0.817 & & & \\
\hline & Info3 & 0.781 & & & \\
\hline \multirow{3}{*}{ Personalization } & Pers1 & 0.759 & \multirow{3}{*}{0.794} & \multirow{3}{*}{0.563} & \multirow{3}{*}{0.187} \\
\hline & Pers2 & 0.577 & & & \\
\hline & Pers3 & 0.691 & & & \\
\hline \multirow{3}{*}{ Trendiness } & Trend1 & 0.543 & \multirow{3}{*}{0.745} & \multirow{3}{*}{0.500} & \multirow{3}{*}{0.324} \\
\hline & Trend2 & 0.703 & & & \\
\hline & Trend3 & 0.844 & & & \\
\hline \multirow{3}{*}{ Word-Of-Mouth (WOM) } & WOM1 & 0.698 & \multirow{3}{*}{0.802} & \multirow{3}{*}{0.577} & \multirow{3}{*}{0.123} \\
\hline & WOM2 & 0.853 & & & \\
\hline & WOM3 & 0.718 & & & \\
\hline \multirow{3}{*}{ Trust } & TR1 & 0.915 & \multirow{3}{*}{0.876} & \multirow{3}{*}{0.703} & \multirow{3}{*}{0.075} \\
\hline & TR2 & 0.854 & & & \\
\hline & TR3 & 0.737 & & & \\
\hline \multirow{3}{*}{ Satisfaction } & Sat1 & 0.881 & \multirow{3}{*}{0.878} & \multirow{3}{*}{0.708} & \multirow{3}{*}{0.071} \\
\hline & Sat2 & 0.876 & & & \\
\hline & Sat3 & 0.761 & & & \\
\hline \multirow{4}{*}{ Commitment } & Com1 & 0.854 & \multirow{4}{*}{0.903} & \multirow{4}{*}{0.699} & \\
\hline & Com2 & 0.854 & & & 0.324 \\
\hline & Com3 & 0.835 & & & $0.0<4$ \\
\hline & Com4 & 0.799 & & & \\
\hline & PI1 & 0.786 & & & \\
\hline Purchase Intention & PI2 & 0.809 & 0.827 & 0.546 & 0.103 \\
\hline turchase imtertion & PI3 & 0.690 & & & \\
\hline & $\mathrm{PI} 4$ & 0.659 & & & \\
\hline
\end{tabular}

Table 3. Construct validity and inter-construct correlations.

\begin{tabular}{|c|c|c|c|c|c|c|c|c|c|}
\hline & Pers & Com & PI & Sat & Info & TR & Inter & WOM & Trend \\
\hline Pers & 0.750 & & & & & & & & \\
\hline Com & 0.367 & 0.836 & & & & & & & \\
\hline PI & 0.312 & 0.321 & 0.739 & & & & & & \\
\hline Sat & 0.084 & 0.267 & 0.156 & 0.841 & & & & & \\
\hline Info & -0.031 & 0.151 & -0.074 & 0.114 & 0.822 & & & & \\
\hline TR & 0.046 & 0.158 & 0.029 & 0.138 & 0.100 & 0.839 & & & \\
\hline Inter & 0.031 & 0.059 & 0.058 & 0.079 & 0.273 & 0.081 & 0.753 & & \\
\hline WOM & 0.093 & 0.255 & 0.160 & 0.140 & 0.306 & 0.273 & 0.351 & 0.759 & \\
\hline Trend & 0.271 & 0.569 & 0.281 & 0.095 & 0.089 & -0.018 & 0.068 & 0.105 & 0.707 \\
\hline
\end{tabular}




\subsubsection{CFA Second Order}

The results of CFA Second Order indicate a good measurement model fit of the proposed factor structure $(\mathrm{CMIN} / \mathrm{DF}=1.610, \mathrm{GFI}=0.887, \mathrm{NFI}=0.864, \mathrm{IFI}=0.944, \mathrm{TLI}=0.937$, $\mathrm{CFI}=0.943, \mathrm{PCFI}=0.850, \mathrm{RMSEA}=0.045, \mathrm{RMR}=0.056)$. Thus, the measurement model fitness was achieved in the pooled CFA Second Order. From Tables 4 and 5, the results find no serious issues in the validity and reliability of each data. All findings concerning the "factor loadings", "construct validity", "reliability", and the model fit indices observed that the findings fulfilled all the prerequisites for the "CFA Second Order" tests. The model measurement could have proceeded to the next level of test viz. the Structural Equation Modelling (SEM) as required in this study.

\subsubsection{Structural Model}

To determine the most responsive factor influencing costumer-brand relationship and further on purchase intention, three factors were subjected to path analysis. For hypothesis testing, "Structural Equation Modeling (SEM)" was studied as per the "two-step latent variable modeling" method. Prior to examining the test results for the proposed research model, the summary notes were first reviewed. The model-fit indices for the structural model provided evidence of comparatively good model fit $(\mathrm{CMIN} / \mathrm{DF}=2.115, \mathrm{GFI}=0.880$, $\mathrm{NFI}=0.896, \mathrm{IFI}=0.942, \mathrm{TLI}=0.938, \mathrm{CFI}=0.942, \mathrm{PCFI}=0.877, \mathrm{RMSEA}=0.043, \mathrm{RMR}=0.096$ ).

The findings of the present study observed that SMMA has a strong impact on strengthening the costumer-brand relationship with a value of $0.315(p<0.001)$ in the SM environment. This leads to the acceptance of Hypothesis 1 and it was observed that the customer-brand relationship is a mediating variable between SMMA and purchase intention. To measure the "costumer"-brand relationship, three relationship dimensions were considered, namely trust, satisfaction, and commitment. From the result dimension, trust ( $\beta=0.656, p<0.001$ ) was found to have significant contribution towards relationship building, followed by satisfaction $(\beta=0.570, p<0.001)$ and commitment $(\beta=0.549$, $p<0.001$ ). Meanwhile, the precise result also shows a significant influence of SMMA on the purchase intention of "costumers" with $0.389(p<0.001)$. Thus, the present study also accepts Hypothesis 2. Further, the study also measures the influence of "costumer"-brand relationships on "costumers'" purchase intentions. The results show a significant relationship, i.e., 0.204 (0.005), which leads us to accept Hypothesis 3. An outline of the hypotheses is presented in Table 6, which includes standardized as well as unstandardized estimates, t-value, and statistical significance level $3.15(\alpha)$. Figure 2 is exhibits the schematic representation of the results of the "structural model", along with significantly found standardized path coefficients level. Herein, all the structural paths are represented at significant levels $(p<0.001$ and $p<0.005)$.

Table 4. Loadings of CFA Second Order.

\begin{tabular}{|c|c|c|c|c|c|}
\hline Constructs & Code & CFA Loadings & C.R. & AVE & MSV \\
\hline \multirow{5}{*}{ SMMA } & Inter & 0.577 & \multirow{5}{*}{0.783} & \multirow{5}{*}{0.551} & \multirow{5}{*}{0.148} \\
\hline & Info & 0.485 & & & \\
\hline & Pers & 0.567 & & & \\
\hline & Trend & 0.626 & & & \\
\hline & WOM & 0.689 & & & \\
\hline \multirow{3}{*}{ CBR } & TR & 0.679 & \multirow{3}{*}{0.736} & \multirow{3}{*}{0.588} & \multirow{3}{*}{0.222} \\
\hline & Sat & 0.581 & & & \\
\hline & Com & 0.557 & & & \\
\hline \multirow{4}{*}{ Purchase Intention } & PI1 & 0.746 & \multirow{4}{*}{0.827} & \multirow{4}{*}{0.546} & \multirow{4}{*}{0.264} \\
\hline & PI2 & 0.759 & & & \\
\hline & PI3 & 0.640 & & & \\
\hline & PI4 & 0.619 & & & \\
\hline
\end{tabular}


Table 4. Cont.

\begin{tabular}{|c|c|c|c|c|c|}
\hline Constructs & Code & CFA Loadings & C.R. & AVE & MSV \\
\hline \multirow{3}{*}{ Interactivity } & Inter1 & 0.735 & & & \\
\hline & Inter2 & 0.781 & & & \\
\hline & Inter3 & 0.633 & & & \\
\hline \multirow{3}{*}{ Informativeness } & Info1 & 0.826 & & & \\
\hline & Info2 & 0.717 & & & \\
\hline & Info3 & 0.741 & & & \\
\hline \multirow{3}{*}{ Personalization } & Pers1 & 0.719 & & & \\
\hline & Pers2 & 0.527 & & & \\
\hline & Pers3 & 0.641 & & & \\
\hline \multirow{3}{*}{ Trendiness } & Trend1 & 0.513 & & & \\
\hline & Trend2 & 0.663 & & & \\
\hline & Trend3 & 0.784 & & & \\
\hline \multirow{3}{*}{ WOM } & WOM1 & 0.658 & & & \\
\hline & WOM2 & 0.793 & & & \\
\hline & WOM3 & 0.678 & & & \\
\hline \multirow{3}{*}{ Trust } & TR1 & 0.885 & & & \\
\hline & TR2 & 0.814 & & & \\
\hline & TR3 & 0.387 & & & \\
\hline \multirow{3}{*}{ Satisfaction } & Sat1 & 0.761 & & & \\
\hline & Sat2 & 0.836 & & & \\
\hline & Sat3 & 0.721 & & & \\
\hline \multirow{4}{*}{ Commitment } & Com1 & 0.814 & & & \\
\hline & Com2 & 0.818 & & & \\
\hline & Com3 & 0.775 & & & \\
\hline & Com4 & 0.759 & & & \\
\hline
\end{tabular}

Table 5. Construct validity and inter-construct correlations.

\begin{tabular}{cccc}
\hline & PI & SMMA & CBR \\
\hline PI & 0.739 & & \\
\hline SMMA & 0.514 & 0.742 & \\
\hline CBR & 0.339 & 0.956 & 0.767 \\
\hline
\end{tabular}

The study also examines the impact of five constructs such as "Interactivity", "Informativeness", "Personalization", "Trendiness", and "Word-of-Mouth" on SMMA of a fashion brand on Facebook. The results revealed all five constructs to be significantly contributing to the SMM activities of fashion brands on Facebook pages. Word-of-Mouth $(\beta=0.667, p<0.001)$ was found to have been highly influential in contributing to SMM activities, followed by trendiness $(\beta=0.631, p<0.001)$, interactivity $(\beta=0.544, p<0.001)$, personalization $(\beta=0.545, p<0.001)$, and informativeness $(\beta=0.472, p<0.001)$. Though the construct informativeness was found to have a low impact, it still plays a significant role in conveying the brand-related messages to the large audience.

Table 6. Result of the SEM model.

\begin{tabular}{cccccccccc}
\hline Hypotheses & & & & $\begin{array}{c}\text { Standardized } \\
\text { Estimate }\end{array}$ & $\begin{array}{c}\text { Unstandardized } \\
\text { Estimate }\end{array}$ & S.E. & C.R. & $p$ \\
\hline H1 & SMMA & $\rightarrow$ & CBR & 0.315 & 0.312 & 0.056 & 5.547 & 0.001 \\
\hline $\mathrm{H} 2$ & SMMA & $\rightarrow$ & PI & 0.389 & 0.543 & 0.076 & 7.117 & 0.001 \\
\hline H3 & CBR & $\rightarrow$ & PI & 0.145 & 0.204 & 0.072 & 2.839 & 0.005 \\
\hline
\end{tabular}




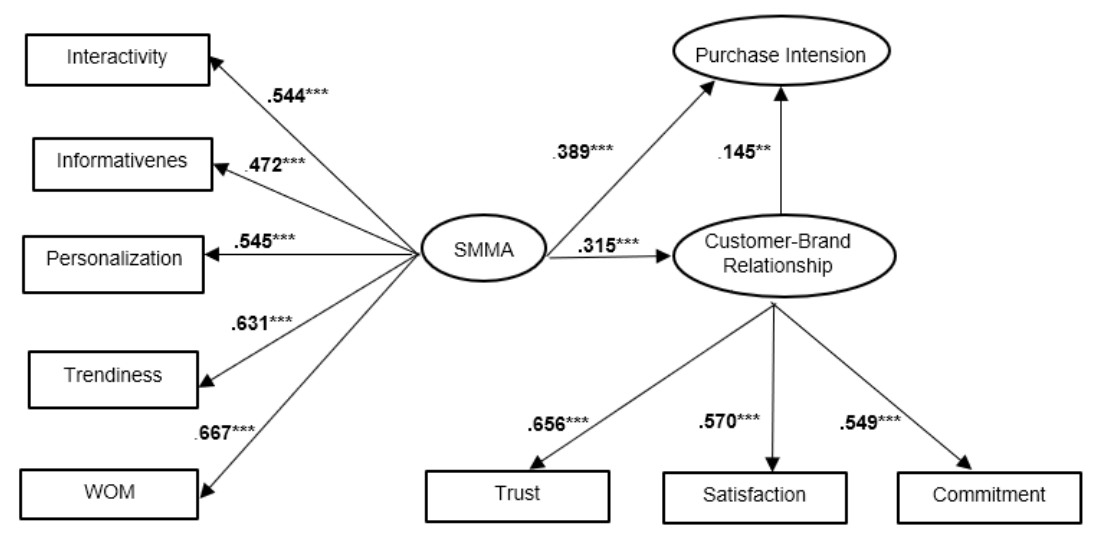

Figure 2. Flow diagram of results obtained on SEM $\left(* * * p<0.001 ;{ }^{* *} p<0.005\right)$.

\section{Discussion}

SM has now become an essential component as a communication channel in daily life, in which customers represent their consumer behavior, preferences, views, likes, and affairs, and communicate with others [5]. In this wide-ranging area of communications, customers can communicate easily with each other and other users, products, and communication activities such as price, time, and easy reach, and large consumer groups are given important opportunities [17,83-85]. Many companies are creating their own SM communication channel to show brand profiles and are developing operations that engage customers to share content such as online products, discounts, advertising, and promotions. The present study attempted to study the impact of SMMA of fashion branding on "consumer-brand relationship" and "purchase intention". Further, the study also measures the impact of relationship quality on "consumers' purchase intentions". The result of the study is supported by the proposed hypothesis.

The present study is related to the SMMA of fashion brands on Facebook pages comprised of five components, out of which WOM activities were found to have a high impact in terms of involving users in SM platforms like Facebook [83]. It has been observed that SM users mostly involved themselves with activities like sharing and recommending fashion-related brands or products with their friends and colleagues, that seems to be are important, useful, and fashionable for them. Similarly, trendiness has also a significant impact on the SMMA of fashion brands. SM users enjoy learning about new trends in the present scenario. Tastes and preferences in the fashion industry keep on changing, therefore the SM users involve themselves more in SMMA to gain knowledge on the recent trends in the market [6,17]. Herein, personalization and interactivity activities also play an essential role in contributing to SMMA, as the users receive only customized information that directly corresponds to the taste and preferences of the "costumers". Moreover, "costumers" also experience Facebook in a user-friendly manner with various features, which enables them to interact and share their opinions about fashion brands with other communities. The informativeness activities were found to have a low impact on the SMMA of fashion brands. This implies that informative posts on the fashion brand pages do not attract the attention of "costumers". Many studies acknowledge that once the brand or product becomes known to everyone, they do not take much interest in the brand or product. However, when this information relates to some entertaining elements, the informative posts become amazingly effective and attract more views $[17,83]$. The results obtained from this study conform with the previous study of Kim and Ko [44], and Yadav and Rahman [28]. The present study validates the measurement items of five dimensions of SMMA such as "Interactivity", "Informativeness", "Personalization", "Trendiness", and "WOM", which were considered to measure the level of involvement with different SM related activities with the fashion brands $[17,27,51,83]$.

For the first time, the present study has measured the impact of SMMA on a consumerbrand relationship. To measure the quality of relationships, three dimensions were con- 
sidered from the literature, namely trust, satisfaction, and commitment. From the results, it is evident that the SMMA of fashion brands on Facebook have a significant impact on the costumer-brand relationship, which is supported by another investigator [83]. This implies that when "costumers" involve themselves with the activities of WOM, trendiness, personalization, interactions, and informativeness in SM platforms like Facebook, the consumers gradually develop trust towards the fashion brands, experience more satisfaction with the fashion brands, and feel more committed towards that particular fashion brand. Further, when examining the dimensions of the relationship, the trust element was found to have a high impact on the relationship-building, followed by satisfaction and commitment. The present study has validated the measurement items of three dimensions based on "trust, satisfaction, and commitment", which were considered to measure the level of customers' relationship concerning the brand [17]. For the practical implications, the marketing managers should focus on engaging "costumers" with various brand-related activities on various social media platforms so that they can create a strong and permanent relationship with "costumers".

Further, the present study examined the association of SMMA on customers' intention to purchase. The findings showed a positive relationship between both the constructs. This implies that when "costumers" involve themselves with the activities of fashion brands in SM platforms like Facebook, their intention of purchasing that specific brand or product grows stronger, and they feel the readiness to pay for that fashion brand. The current study is also supported by the earlier findings of Yadav and Rahman [28], who also found a positive impact of SMMA on "costumers"' purchasing intention. For the practical implications, the companies should include SM in a manner that provides maximum interaction, precise details on goods, personalized product suggestions, and trendy items to encourage consumers to share favorable WOM $[17,83]$, because these activities will further affect consumers' purchase intentions, and then will generate leads by converting them into actual purchases.

\section{Conclusions}

It is concluded that the "costumer"-brand relationship does have a positive impact on "costumers" purchase intention through SM. This implies that when the "costumers" develop trust towards the fashion brands, they more satisfaction and commitment is observed towards specific brands, which indicates strong purchase intension among customers. As per practical implications, the marketing managers should focus on creating trust, satisfaction, and commitment through various brand-related activities so that customers' purchase intension may be induced. Finally, this investigation may help customer-brand relationship on perceived SMMA based e-commerce technology that would help retailers to understand the customers and streamline their business strategy.

\section{Limitations and Future Research Directions}

No research is completely flawless, and all come with certain limitations. This study also possesses some limitations, as the study has been carried out considering only one aspect of SMM, i.e., Facebook. However, as we are living in the 21st century, the digital era, the organizations of the present day are innovative, and the work process has changed. Quick output is expected everywhere. On the other hand, several organizations are using "Twitter", "Instagram", "Blogs", "Wikis", etc. It is emphasized that further studies should cover some more dimensions of SMMA to understand how organizations are using SM under varied circumstances. Secondly, the sample size considered was only 305, which brings some limitations. If the work was with a larger sample size, like 800 or 1000, then it may have found a wider conception regarding SMMA. The study was comprised of respondents from capital cities and metro city of eastern India. However, it can be extended to some smaller states that would help to get some more inputs about how people perceive SMMA. In future, a comparative study between India and other developed countries might 
be an informative research. It is also under a new research goal that socioeconomic and demographic variables of participants may enhance the SMMA.

Author Contributions: Conceptualization, S.S. (Saumya Singh) and G.D.; Methodology, S.S. (Saumya Singh) and G.D.; Statistical Software analysis, S.S. (Sukanya Sharma); Validation, S.S. (Saumya Singh) and G.D., F.K. and S.S. (Sukanya Sharma); Formal Analysis, S.S. (Sukanya Sharma); Investigation, S.S. (Sukanya Sharma); Resources, S.S. (Sukanya Sharma); Data Curation, S.S. (Sukanya Sharma) and F.K.; Writing-S.S. (Sukanya Sharma); Writing-Review \& Editing, S.S. (Sukanya Sharma), S.S. (Saumya Singh); Visualization, S.S. (Saumya Singh); Supervision, S.S. (Saumya Singh) and G.D. All authors have read and agreed to the published version of the manuscript.

Funding: This research received no external funding.

Acknowledgments: All authors convey thanks to all participants for their support during survey. We are privileged to provide an opportunity for carrying out the present investigation with the help of the Head of the Institute, Rajiv Shekhar, Director, Indian Institute of Technology (Indian School of Mines), Jharkhand, India.

Conflicts of Interest: The authors declare no conflict of interest.

\section{References}

1. Ellison, N.B.; Gibbs, J.L.; Weber, M.S. The Use of Enterprise Social Network Sites for Knowledge Sharing in Distributed Organizations. Am. Behav. Sci. 2014, 59, 103-123. [CrossRef]

2. Utz, S.; Breuer, J. Informational benefits from social media use for professional purposes: Results from a longitudinal study. Cyberpsychol. J. Psychosoc. Res. Cyberspace 2016, 10. [CrossRef]

3. Jaring, P.; Bäck, A. How researchers use social media to promote their research and network with industry. Technol. Innov. Manag. Rev. 2017, 7, 32-39. [CrossRef]

4. Tenhunen, A. Digital Marketing Plan for VTT's Conventional and Renewable Energy Solutions. Master's Thesis, University of Oulu, Oulu, Finland, 2017.

5. Kapoor, K.K.; Tamilmani, K.; Rana, N.P.; Patil, P.P.; Dwivedi, Y.K.; Nerur, S. Advances in Social Media Research: Past, Present and Future. Inf. Syst. Front. 2018, 20, 531-558. [CrossRef]

6. Appel, G.; Grewal, L.; Hadi, R.; Stephen, A.T. The future of social media in marketing. J. Acad. Mark. Sci. 2020, 48, 79-95. [CrossRef]

7. Back, M.D.; Stopfer, J.M.; Vazire, S.; Gaddis, S.; Schmukle, S.C.; Egloff, B.; Gosling, S.D. Facebook Profiles Reflect Actual Personality, Not Self-Idealization. Psychol. Sci. 2010, 21, 372-374. [CrossRef]

8. Gosling, S.D.; Gaddis, S.; Vazire, S. Personality impressions based on Facebook profiles. Presented at the International Conference on Weblogs and Social Media, Boulder, CO, USA, 26-28 March 2007; Volume 7, pp. 1-4.

9. Gosling, S.D.; Augustine, A.; Vazire, S.; Holtzman, N.; Gaddis, S. Manifestations of Personality in Online Social Networks: Self-Reported Facebook-Related Behaviors and Observable Profile Information. Cyberpsychol. Behav. Soc. Netw. 2011, 14, 483-488. [CrossRef]

10. Valkenburg, P.M.; Peter, J.; Schouten, A.P. Friend Networking Sites and Their Relationship to Adolescents' Well-Being and Social Self-Esteem. Cyber Psychol. Behav. 2006, 9, 584-590. [CrossRef]

11. Singh, M.; Singh, G. Impact of social media on e-commerce. Int. J. Eng. Technol. 2018, 7, 21-26. [CrossRef]

12. Hwang, I.J.; Lee, B.G.; Kim, K.Y. Information Asymmetry, Social Networking Site Word of Mouth, and Mobility Effects on Social Commerce in Korea. Cyberpsychol. Behav. Soc. Netw. 2014, 17, 117-124. [CrossRef] [PubMed]

13. Ahmad, N.; Salman, A.; Ashiq, R. The impact of social media on fashion industry: Empirical investigation from Karachiites. J. Resour. Dev. Manag. 2015, 7,1-7.

14. Moran, N. Social marketing meets interactive media: Lessons for the advertising community. Strat. Dir. 2012, 28. [CrossRef]

15. Sarkar, A. The Impact of Social Media Marketing on Customers Preferences in Fashion Industry. Master's Thesis, Department of Management Studies, Sri Venkateshwara College of Engineering and Technology, Tamil Nadu, India, 2019.

16. Naqvi, B.; Soni, S.; Naqvi, B.; Soni, S. The Rise and Growth of the Indian Retail Industry. Indiaretailing, 29 August 2019. Available online: https:/ / www.indiaretailing.com/2019/08/29/retail/the-rise-and-growth-of-the-indian-retail-industry/ (accessed on 10 March 2020).

17. Kujur, F.; Singh, S. Visual Communication and Consumer-Brand Relationship on Social Networking Sites-Uses \& Gratifications Theory Perspective. J. Theor. Appl. Electron. Commer. Res. 2020, 15, 30-47. [CrossRef]

18. Mirabi, V.; Akbariyeh, H.; Tahmasebifard, H. A study of factors affecting on customers purchase intention. J. Multidiscip. Eng. Sci. Technol. 2015, 2, 267-273.

19. Hajli, M.N. A study of the impact of social media on consumers. Int. J. Mark. Res. 2014, 56, 387-404. [CrossRef]

20. Lamberton, C.P.; Naylor, R.W.; Haws, K.L.; Reczek, R.W. Same destination, different paths: When and how does observing others' choices and reasoning alter confidence in our own choices? J. Consum. Psychol. 2013, 23, 74-89. [CrossRef]

21. Norton, D.A.; Lamberton, C.P.; Naylor, R.W.; Reczek, R.W. The Devil You (Don't) Know: Interpersonal Ambiguity and Inference Making in Competitive Contexts. J. Consum. Res. 2013, 40, 239-254. [CrossRef] 
22. Wilcox, K.; Stephen, A.T. Are Close Friends the Enemy? Online Social Networks, Self-Esteem, and Self-Control. J. Consum. Res. 2013, 40, 90-103. [CrossRef]

23. Pham, P.H.; Gammoh, B.S. Characteristics of social-media marketing strategy and customer-based brand equity outcomes: A conceptual model. Int. J. Internet Mark. Advert. 2015, 9, 321. [CrossRef]

24. Stephenson, L. From Blogs to Twitter, Fashion World Rushes to Tap into Social media. Women's Wear Dly. 2009, $197,131$.

25. Kim, A.J.; Ko, E. Impacts of Luxury Fashion Brand's Social Media Marketing on Customer Relationship and Purchase Intention. J. Glob. Fash. Mark. 2010, 1, 164-171. [CrossRef]

26. Bilgin, Y. The effect of social media marketing activities on brand awareness, brand image and brand loyalty. Bus. Manag. Stud. Int. J. 2018, 6, 128-148. [CrossRef]

27. Kim, A.J.; Ko, E. Do social media marketing activities enhance customer equity? An empirical study of luxury fashion brand. J. Bus. Res. 2012, 65, 1480-1486. [CrossRef]

28. Yadav, M.; Rahman, Z. Measuring consumer perception of social media marketing activities in e-commerce industry: Scale development \& validation. Telemat. Inform. 2017, 34, 1294-1307.

29. Oliver, C. Social Networks Change the Online Retail Game. Available online: http://www.itworld.com/internet/59323/socialnetworks-changeonline-retail-game (accessed on 11 February 2011).

30. Richter, A.; Koch, M. Social Software-Status quo und Zukunft; Technischer Bericht, Fakultatfür Informatik, Universitat der Bundeswehr München: Munchen, Germany, 2007.

31. Kamboj, S.; Sarmah, B.; Gupta, S.; Dwivedi, Y. Examining branding co-creation in brand communities on social media: Applying the paradigm of Stimulus-Organism-Response. Int. J. Inf. Manag. 2018, 39, 169-185. [CrossRef]

32. Smith, H.J.; Pettigrew, T.F.; Pippin, G.M.; Bialosiewicz, S. Relative Deprivation. Pers. Soc. Psychol. Rev. 2011, 16, 203-232. [CrossRef]

33. Burmann, C. A call for 'User-Generated Branding'. J. Brand Manag. 2010, 18, 1-4. [CrossRef]

34. Rialti, R.; Zollo, L.; Pellegrini, M.M.; Ciappei, C. Exploring the Antecedents of Brand Loyalty and Electronic Word of Mouth in Social-Media-Based Brand Communities: Do Gender Differences Matter? J. Glob. Mark. 2017, 30, 147-160. [CrossRef]

35. Hon, L.C.; Grunig, J.E. Guidelines for Measuring Relationships in Public Relations. Gold Standard Paper of the Commission on Public Relations Measurement \& Evaluation; Institute for Public Relations, University of Florida: Gainesville, FL, USA, 1999.

36. Men, L.R.; Tsai, W.-H.S. Perceptual, Attitudinal, and Behavioral Outcomes of Organization-Public Engagement on Corporate Social Networking Sites. J. Public Relat. Res. 2014, 26, 417-435. [CrossRef]

37. Ulaga, W.; Eggert, A. Value-Based Differentiation in Business Relationships: Gaining and Sustaining Key Supplier Status. J. Mark. 2006, 70, 119-136. [CrossRef]

38. McKnight, D.H.; Chervany, N.L. Trust and Distrust Definitions: One Bite at a Time. In Computer Vision-ECCV 2020; Falcone, R., Singh, M., Tan, Y.H., Eds.; Springer Science and Business Media LLC.: Berlin/Heidelberg, Germany, 2001; pp. 27-54.

39. Hung, W. The 3C3R Model: A Conceptual Framework for Designing Problems in PBL. Interdiscip. J. Probl. Learn. 2006, 1, 55-77. [CrossRef]

40. Grunig, J.E.; Huang, Y.H. From organizational effectiveness to relationship indicators: Antecedents of relationships, public relations strategies, and relationship outcomes. In Relationship Management: A Relation Approach to the Study and Practice of Public Relations; Ledingham, J.A., Bruning, S.D., Eds.; Lawrence Elbaum Associates: Mahwah, NJ, USA, 2000; pp. 25-33.

41. Kujur, F.; Singh, S. Emotions as predictor for consumer engagement in YouTube advertisement. J. Adv. Manag. Res. 2018, 15, 184-197. [CrossRef]

42. Bortree, D.S. Mediating the power of antecedents in public relationships: A pilot study. Public Relat. Rev. 2011, 37, 44-49. [CrossRef]

43. Nammir, D.S.S.; Marane, B.M.; Ali, A.M. Determine the role of customer engagement on relationship quality and relationship performance. Eur. J. Bus. Manag. 2012, 4, 27-36.

44. Younus, S.; Rasheed, F.; Zia, A. Identifying the factors affecting customer purchase intention. Glob. J. Manag. Bus. Res. Adm. Manag. 2015, 15, 9-13.

45. Kim, A.J.; Johnson, K.K.P. Power of consumers using social media: Examining the influences of brand-related user-generated content on Facebook. Comput. Hum. Behav. 2016, 58, 98-108. [CrossRef]

46. Diallo, M.F. Effects of store image and store brand price-image on store brand purchase intention: Application to an emerging market. J. Retail. Consum. Serv. 2012, 19, 360-367. [CrossRef]

47. Das, G. Linkages of retailer personality, perceived quality and purchase intention with retailer loyalty: A study of Indian non-food retailing. J. Retail. Consum. Serv. 2014, 21, 407-414. [CrossRef]

48. Luo, M.M.; Chen, J.-S.; Ching, R.K.; Liu, C.-C. An examination of the effects of virtual experiential marketing on online customer intentions and loyalty. Serv. Ind. J. 2010, 31, 2163-2191. [CrossRef]

49. Leitão, J.; Fernandes, C.; Raposo, M. Social Media Marketing: A Literature Review and Implications. Psychol. Mark. 2016, 33, 1029-1038.

50. Cambria, E.; Grassi, M.; Hussain, A.; Havasi, C. Sentic Computing for social media marketing. Multimed. Tools Appl. 2012, 59, 557-577. [CrossRef]

51. Ismail, A.R.; Nguyen, B.; Melewar, T. Impact of perceived social media marketing activities on brand and value consciousness: Roles of usage, materialism and conspicuous consumption. Int. J. Internet Mark. Advert. 2018, 12, 233. [CrossRef]

52. Leung, X.Y.; Bai, B.; Stahura, K.A. The Marketing Effectiveness of Social Media in the Hotel Industry. J. Hosp. Tour. Res. 2013, 39, 147-169. [CrossRef] 
53. Yu, Y.; Duan, W.; Cao, Q. The impact of social and conventional media on firm equity value: A sentiment analysis approach. Decis. Support Syst. 2013, 55, 919-926. [CrossRef]

54. Homburg, C.; Koschate, N.; Hoyer, W.D. The Role of Cognition and Affect in the Formation of Customer Satisfaction: A Dynamic Perspective. J. Mark. 2006, 70, 21-31. [CrossRef]

55. Verhoef, P.C.; Franses, P.H.; Hoekstra, J.C. The Effect of Relational Constructs on Customer Referrals and Number of Services Purchased from a Multiservice Provider: Does Age of Relationship Matter? J. Acad. Mark. Sci. 2002, 30, 202-216. [CrossRef]

56. Cronin, J.J.; Taylor, S.A. Measuring Service Quality: A Reexamination and Extension. J. Mark. 1992, 56, 55. [CrossRef]

57. Bloemer, J.; de Ruyter, K.; Peeters, P. Investigating derivers of bank loyalty: The complex relationship between image, service quality and satisfaction. Int. J. Bank Mark. 1998, 16, 276-286. [CrossRef]

58. Kuo, Y.-F.; Wu, C.-M.; Deng, W.-J. The relationships among service quality, perceived value, customer satisfaction, and postpurchase intention in mobile value-added services. Comput. Hum. Behav. 2009, 25, 887-896. [CrossRef]

59. Ajzen, I. The theory of planned behavior. Organ. Behav. Hum. Decis. Process. 1991, 50, 179-211. [CrossRef]

60. Armitage, C.J.; Conner, M. Efficacy of the theory of planned behavior: A meta-analytic review. Br. J. Soc. Psychol. 2001, 40, 471-499. [CrossRef] [PubMed]

61. Bennett, R.; Rundle-Thiele, S. A comparison of attitudinal loyalty measurement approaches. J. Brand Manag. 2002, 9, 193-209. [CrossRef]

62. Motameni, R.; Shahrokhi, M. Brand equity valuation: A global perspective. J. Prod. Brand Manag. 1998, 7, 275-290. [CrossRef]

63. Kotler, P.; MichaelAllen, H.; Rein, I.; Donald, H. Marketing Asian Places; John Wiley \& Sons: Hoboken, NJ, USA, 2001.

64. Narang, R. A study on branded men's wear. Indian J. Mark. 2006, 36, 39.

65. Kamalaveni, D.K.; Rajalakshmi, S.; Kalaiselvi, S. Brand loyalty of women consumers with respect to FMCGs. Indian J. Mark. 2008, 38,9 .

66. Beneke, J.; Carter, S.R. The development of a consumer value proposition of private label brands and the application thereof in a South African retail context. J. Retail. Consum. Serv. 2015, 25, 22-35. [CrossRef]

67. Granot, E.; Greene, H.; Brashear, T.G. Female consumers: Decision-making in brand-driven retail. J. Bus. Res. 2010, 63, 801-808. [CrossRef]

68. Beristain, J.J.; Zorrilla, P. The relationship between store image and store brand equity: A conceptual framework and evidence from hypermarkets. J. Retail. Consum. Serv. 2011, 18, 562-574. [CrossRef]

69. Erdil, T.S.; Uzun, Y. Marka Olmak, 2nd ed.; Beta Publishing: Istanbul, Turkey, 2010.

70. Kumar, A.; Kim, Y.-K. The store-as-a-brand strategy: The effect of store environment on customer responses. J. Retail. Consum. Serv. 2014, 21, 685-695. [CrossRef]

71. Rayburn, S.W.; Voss, K.E. A model of consumer's retail atmosphere perceptions. J. Retail. Consum. Serv. 2013, 20, 400-407. [CrossRef]

72. Koivulehto, E.I. Do Social Media Marketing Activities Enhance Customer Equity? A Case Study of Fast Fashion Brand Zara; Aalto University: Helsinki, Finland, 2017.

73. Seo, E.-J.; Park, J.-W. A study on the effects of social media marketing activities on brand equity and customer response in the airline industry. J. Air Transp. Manag. 2018, 66, 36-41. [CrossRef]

74. Hung, K.; Chen, A.H.; Peng, N.; Hackley, C.; Tiwsakul, R.A.; Chou, C. Antecedents of luxury brand purchase intention. J. Prod. Brand Manag. 2011, 20, 457-467. [CrossRef]

75. Park, D.-H.; Lee, J.; Han, I. The Effect of On-Line Consumer Reviews on Consumer Purchasing Intention: The Moderating Role of Involvement. Int. J. Electron. Commer. 2007, 11, 125-148. [CrossRef]

76. EChong, E.; Nazim, A.; Ahmad, S.B. A comparison between individual confirmatory factor analysis and pooled confirmatory factor analysis: An analysis of library service quality, a case study at a public university in Terengganu. Int. J. Eng. Sci. Innov. Technol. 2014, 3, 110-116.

77. Byrne, B.M. Multivariate Applications Series. Structural Equation Modeling with AMOS: Basic Concepts, Applications, and Programming, 2nd ed.; Routledge: London, UK; Taylor \& Francis Group: Abingdon, UK, 2010.

78. Hair, J.F.; Black, W.C.; Babin, B.J.; Anderson, R.E. Multivariate Data Analysis, 7th ed.; Prentice Hall: Upper Saddle River, NJ, USA, 2010

79. Kenny, D.A.; Kashy, D.A. Analysis of the multitrait-multimethod matrix by confirmatory factor analysis. Psychol. Bull. 1992, 112, 165-172. [CrossRef]

80. Kline, R.B. Methodology in the Social Sciences. Principles and Practice of Structural Equation Modeling, 3rd ed.; Guilford Press: New York, NY, USA, 2011.

81. Chua, Y.P. Asas statistik Penyelidikan: Analisis Data Skala Ordinal Dan Skala Nominal; McGraw-Hill: Noida, India, 2009.

82. Rosseni, D. Pembinaan E Permodelan Sistem Pengajaran; Penerbit Universiti Kebangsaan: Bangi, Malaysia, 2014.

83. Ismagilova, E.; Slade, E.L.; Rana, N.P.; Dwivedi, Y.K. The effect of characteristics of source credibility on consumer behaviour: A meta-analysis. J. Retail. Consum. Serv. 2020, 53. [CrossRef]

84. Shareef, M.A.; Mukerji, B.; Dwivedi, Y.K.; Rana, N.P.; Islam, R. Social media marketing: Comparative effect of advertisement sources. J. Retail. Consum. Serv. 2018, 46, 58-69. [CrossRef]

85. Shiau, W.-L.; Dwivedi, Y.K.; Lai, H.-H. Examining the core knowledge on facebook. Int. J. Inf. Manag. 2018, 43, 52-63. [CrossRef] 